\title{
Expression of the oncogenes mil and ras abolishes the in vivo differentiation of mammary epithelial cells
}

\author{
Walter H.Günzburg ${ }^{1,2,3}$, Brian Salmons', Alex Schlaeffli², \\ Sylviane Moritz-Legrand", Walis Jones ${ }^{2,4}$, \\ Nurul H.Sarkar ${ }^{1}$ and Robert Ullrich ${ }^{5}$ \\ 'Department of Cell and Molecular Biology, Medical College of Georgia, \\ Augusta, GA 30912, USA, ${ }^{2}$ Ludwig Institute for Cancer Research, Bern \\ Branch, Inselspital, CH-3010 Bem, Switzerland and ${ }^{5}$ Oak Ridge National \\ Laboratory, Biology Division, Oak Ridge, TN 37831, USA \\ ${ }^{3}$ Present address, and address to which requests for reprints should be sent: \\ GSF-München, Abteilung für Molekulare Zellpathologie, Ingolstädter \\ Landstrasse 1, D-8042 Neuherberg, FRG \\ ${ }^{4}$ Present address: Department of Biochemistry, Glaxo Group Research, \\ Greenford, Middlesex UB6 OHE, UK
}

Three carcinoma-associated oncogenes, two of which have been strongly implicated in human mammary tumorigenesis, have been introduced into a novel mouse mammary epithelial cell line, EF43, that retains many differentiated functions. The effect of oncogene expression upon classical transformation parameters as well as parameters specific for mammary epithelial cells such as growth in three-dimensional collagen matrices and the ability to repopulate the cleared mammary fat pad and to form alveolar structures in vivo has been investigated. Expression of $v-m y c$ in EF43 cells results in no obvious phenotypic changes, and does not confer tumorigenic potential upon the cells. Expression of v-Ha-ras confers upon EF43 cells the ability to grow rapidly, grow in an anchorageindependent manner, results in tumor formation in nude and syngeneic animals, abolishes their ability to repopulate the mammary gland and, instead, results in rapid induction of anaplastic tumors. The v-mil oncogene, an avian homolog of the mouse v-mht and human c-raf oncogenes, previously thought to be non-transforming in the absence of a cooperating oncogene, transforms EF43 cells, allowing them to grow in an anchorage-independent manner, form tumors in nude mice and abolishes their ability to repopulate the cleared mammary fat pad. In contrast to v-ras, however, the tumors arking from $v$-mil expression have a differentiated morphology, typical of adenocarcinomas. Thus, different oncogenes show varying degrees of inhibition of the differentiation of mammary epithelial cells in vivo.

\section{Introduction}

Neoplastic transformation of the mammary gland proceeds via a multistep pathway involving the tumorigenic conversion of one or a number of mammary cell types. The identity of the cell types involved in this process, their interaction during the conversion and the identity of the cellular genes which are deregulated is open both to speculation and investigation.

Transfection of DNA from the human mammary tumor derived cell line MCF-7 into NIH/3T3 fibroblasts has identified potential mammary oncogenes (1). Additionally, the Ha-ras oncogene has been found activated or overexpressed in some human mammary

-Abbreviations: EGF, epidermal growth factor, HANs, hyperplastic alveolar nodules. tumors $(2-4)$ and a human mammary tumor cell line $(5,6)$. Two erb- $B$ related genes, the human epidermal growth factor (EGF*) receptor gene $(7,8)$ and the neu oncogene (9) have been found amplified in human mammary carcinoma derived cell lines. More recently, the neu oncogene has been shown to be amplified in primary mammary tumors (10). Similarly, the c-myc gene has been found to be amplified (11) and overexpressed in some human primary breast carcinomas (12).

In the mouse, depending upon strain, either plaques or hyperplastic alveolar nodules (HANs) represent the first visible preneoplastic lesion. HANs, and less frequently plaques, may eventually progress to overt mammary tumors (13). During this progression a number of genes may become activated including the putative mammary oncogenes, int-1 (14), int-2 (15), int-3 (16) and int- $H$ (17). Two of these oncogenes have been shown to be activated early in mammary tumorigenesis $(18,19)$.

Although there is a correlation between expression of oncogenes and the transformed phenotype, a causal relationship between expression and transformation of the normal mammary gland has not yet been demonstrated. In order to determine whether any of the known oncogenes implicated in mammary tumorigenesis are causally involved, we have introduced the activated cellular Ha-ras oncogene, the viral ras and myc oncogenes, and the v-mil oncogene-the murine homolog of which has been implicated in carcinoma formation $(20,21)$-into a normal mouse mammary epithelial cell line, EF43. Although this mammary cell line is able to divide indefinitely in culture, it retains many of the properties of normal mammary epithelial cells, including the ability to repopulate the cleared mammary fat pad and respond to the mammotropic stimuli of pituitary hormones.

The effects of the expression of these genes on classical parameters of transformation such as morphology, anchorageindependent growth and tumorigenicity in nude and syngeneic mice have been investigated. In addition, we have examined the consequences of the expression of these oncogenes upon some properties of differentiated mammary epithelial cells such as the ability to grow in collagen matrices, induction of casein in response to treatment with lactogenic hormones, and repopulation of cleared mammary fat pads. Finally we determined the effects of these oncogenes on the dependence of mammary epithelial cells upon EGF, insulin and serum for growth.

Our data suggest that the introduction and expression of the activated c-Ha-ras or v-Ha-ras and the v-mil oncogene in normal mouse mammary epithelial cells results in tumorigenic conversion and interference with the in vivo differentiation of the cells. In contrast, expression of the $v-m y c$ gene in these cells does not appear to interfere with normal mammary differentiation in terms of the parameters we have measured.

\section{Materials and methods}

\section{Plasmid vectors}

A 1.7-kb BanHI-BgllI fragment containing the v-Ha-ras gene from Harvey murine sarcoma virus (pHaSV; 22) and a 1.5-kb BamHI - Aval fragment containing 

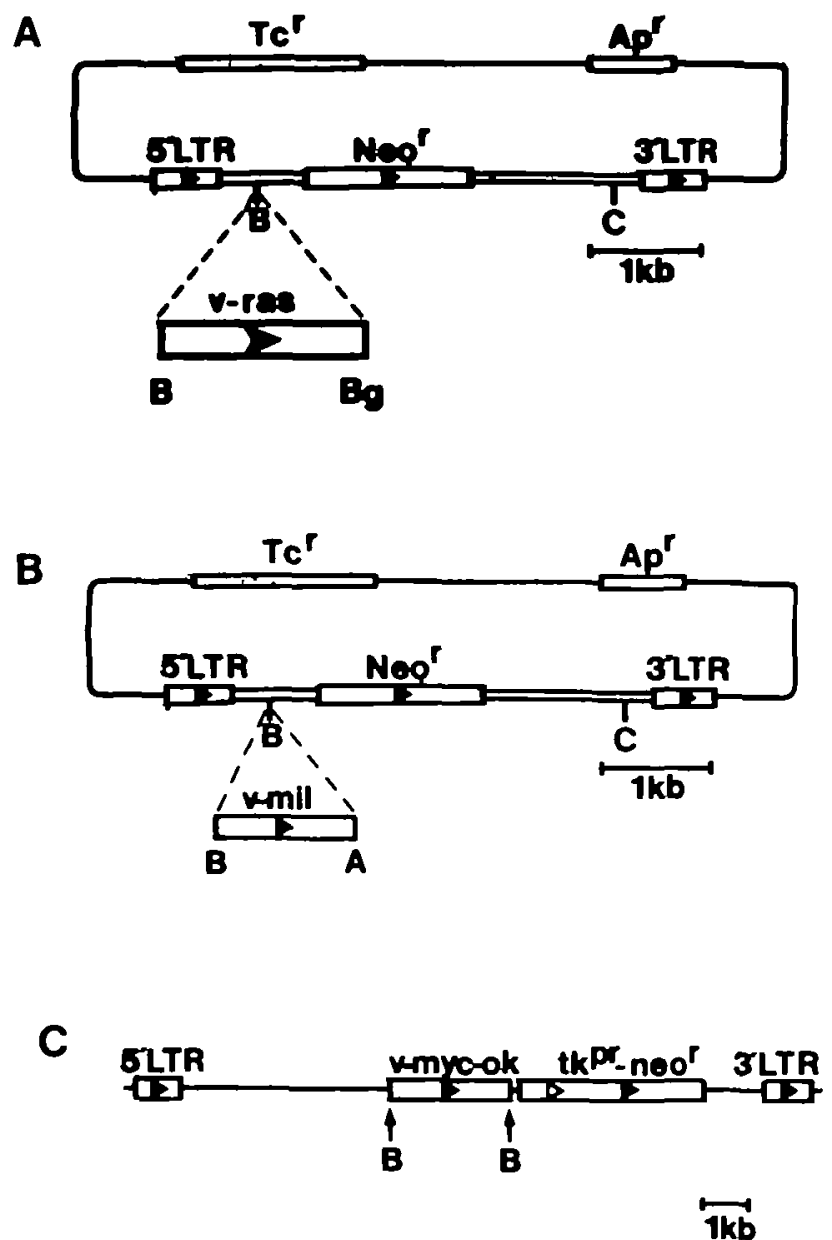

Fig. 1. Schematic diagrams of the plasmids pMMCV-neo (26), pZIPras and pZIPmil. pZIPras and pZIPmil were constructed as outlined in Materials and methods. BamHI sites are designated B, Bg/II sites are designated Bg, Aval sites are designated A, ClaI sites are designated C. The herpes simplex thymidine kinase promoter is marked $\mathrm{t}^{\mathrm{pr}}$ and the direction of the promoter is indicated by open arrows. The neomycin-resistance gene from $\operatorname{Tn}_{5}$ is marked neor. The tetracycline- and ampicillin-resistance genes are indicated $\mathrm{Tc}^{\mathrm{T}}$ and $\mathrm{Ap}^{\mathrm{I}}$ respectively. Direction of gene transcription is indicated by closed arrows.

the v-mil gene of the MH-2 virus (pMH-2-BH; 23) were inserted in the syn orientation into the BamHI site of pZIPneoSV(X) (24) to generate the plasmids pZIP-ras and pZIP-mil respectively (Figure $1 \mathrm{~A}$ and B). The v-myc containing pMMCV-neo plasmid (Figure IC; 25) was kindly provided by B.Vennström, Heidelberg, FRG. The pSV2neo-EJ plasmid was derived from pSV2-neo (26) by the insertion of a $6.6-\mathrm{kb} \mathrm{BamHI}$ fragment of cloned genomic DNA from the plasmid pEJ (27) into the unique BamHI site of pSV2-neo (N.E.Hynes, Ludwig Institute, Bern, unpublishod).

Cell culture, transfections and retroviral infections

EF43 cells were cultured in DMEM supplemented with 10\% fetal bovine serum, 19 penicillin/streptomycin; $1 \mu \mathrm{g} / \mathrm{ml}$ insulin and $5 \mathrm{ng} / \mathrm{ml}$ EGF. Cells were transfected with the plasmid pSV2neo-EJ essentially as outlined previously (28). Stable, neomycin-resistant clones were selected in $200 \mu \mathrm{g} / \mathrm{ml}$ G418. Retroviral infection after transient transfection of $\mathbf{\$ 2}$ cells (29) was carried out as described previously (30).

Test for growh factor dependence

Suspensions of single cells at a density of $1 \times 10^{4}$ were seeded in a $6-\mathrm{cm}$ plate in normal medium. The modium was changed $24 \mathrm{~h}$ later to medium containing combinations of $0.5 \%$ fetal serum, EGF and insulin. Duplicate cultures were counted in a Coulter Counter at this time and 6 days later.

Growth in collagen

Cells were establishod in collagen matrix cultures essentially as described by Jones and Hosick (31). Briefly, $1 \times 10^{5}$ cells were resuspended in $10 \mu \mathrm{l}$ of medium and mixed with $80 \mu \mathrm{l}$ of rat-tail collagen $(1 \mathrm{mg} / \mathrm{ml}, 6 \mu \mathrm{l} / \mathrm{ml} 6.27 \mathrm{mM}$ acetic acid) and $10 \mu$ setting solution $(6 \times \mathrm{RPMI}, 0.075 \mathrm{~N} \mathrm{NaOH}, 0.0245 \mathrm{~g} / \mathrm{ml} \mathrm{NaHCO}$ ). This mixure was plated into a collagen-coated well of a 12-well cluster plate and left to set $15 \mathrm{~min}$ at $37^{\circ} \mathrm{C}$. Two milliliters of medium were then added to each well, the collagen matrices detached from the Petri dish and the collagen cultures incubated for 2-4 weeks under normal conditions with regular medium changes.

Assay for growth in soft agar

Cells $\left(1 \times 10^{5}\right)$ from a single cell suspension were plated into $8 \mathrm{ml}$ of DMEM containing antibrotics, $10 \%$ fetal calf serum and $0.35 \%$ bacto-agar. This was layered into 6-cm Petn dishes precoated with a bottom layer of $2 \times$ soft agar. The soft agar dishes were incubated in moist chambers under normal culture conditions. The appearance of colonies of cells growing in the soft agar was noted after 2 weeks.

Assay for tumorigenicity in nude mice

Cells $\left(1 \times 10^{6}\right)$ from a single cell suspension were washed twice in serum- and pyrogen-free DMEM before being resuspended in $200 \mu \mathrm{l}$ of the same medium. This was injected s.c. into 2-week-old $\mathrm{Nu} / \mathrm{Nu}$ mice under aseptic conditions. The mice were observed once a week for the appearance of tumors at the site of injection.

Repopulation of the cleared mammary fat pad

Cells $\left(1-3 \times 10^{5}\right)$ in serum-free Hanks' medium were injected in a $10-\mu l$ volume into the cleared no.4 fat pads of 18-day-old female BALB/c muce using a 30-gauge Hamilton Syringe (32).

Pituitary isografi procedure

Pituitary isografts were performed using the method of ref. 33. Pituitary donors were killed by cervical dislocation, the pituitary gland removed and inserted into an 18-gauge trocar. Two pituitaries were inserted into the spleen of anesthetized recipient mice. The hormonal activity of the isografts was assessed by evaluating vaginal smears and by microscopic examination of the isograft and mammary glands.

Preparation of whole amounts of mammary fat pads

After ventral incision, the no. 4 mammary glands were removed with the skin flap attached and fixed in acetic acid/ethanol $(1: 3 \mathrm{v} / \mathrm{v})$ for at least $1 \mathrm{~h}$. The glands were washed in $70 \%$ ethanol and then in distilled water before being dissected away from skin. The glands were stained in Alum Carmine solution for at least $4 \mathrm{~h}$, washed with ethanol and then destained in methyl salicylate.

Expression of ancogene products

To test for expression of $221^{\text {ras }}$ in the EF43J series and in EF43zip-ras-pop, cell membrare preparations were made as outlined previously (30). The proteins were separated on a 17\% SDS-polyacrylamide gel, electroblotted to nitrocellulose and reacted with the appropriate antisera and visualized as previously described (30). Anti-p21 $1^{\text {mes }}$ was kindly donated by Dr R.Sweet (Smith, Kline and French Laboratories, Philadelphia, PA). Radiolabeling of cellular protein with $\left[{ }^{35} \mathrm{~S}\right]-$ methionine, extraction and immunoprecipitation of the v-myc and v-mil proteins was performed as outlined previously (28) using anti-myc serum (Cambridge Research Biochemicals) and anti-mil serum, kindly supplied by J.Ghysdael (Institut Pasteur, Lille, France).

\section{Results}

\section{Characterization of EF43 cells}

The mammary epithelial cell line EF43 was derived as a clonal outgrowth from the mammary gland of an irradiated BALB/c female mouse as previously described (34). EF43 cells retain most of the differentiation characteristics of normal mammary epithelium including the formation of normal ductal structures in the cleared mammary fat pads of syngeneic mice (Figure 4A). Further, when these mice receive pituitary isografts, the ductal structures form alveolar outgrowths at a frequency of $60 \%$ (Figure 4A, inset), demonstrating that EF43 cells are capable of responding to the mammotropic effects of pituitary hormones. EF43-derived outgrowths differentiate in pregnant mice and produce milk, regressing to normal ductal structures following weaning of the litter. The EF43 cell line is heterogeneous with respect to keratin expression using the DAKO rabbit anti-human stratum corneum keratin antiserum (results not shown). Heterogeneity in keratin expression has been reported for another mouse mammary cell line that produces mammary outgrowths (35). Taken together, these data suggest that EF43 cells may be mammary progenitor cells. 


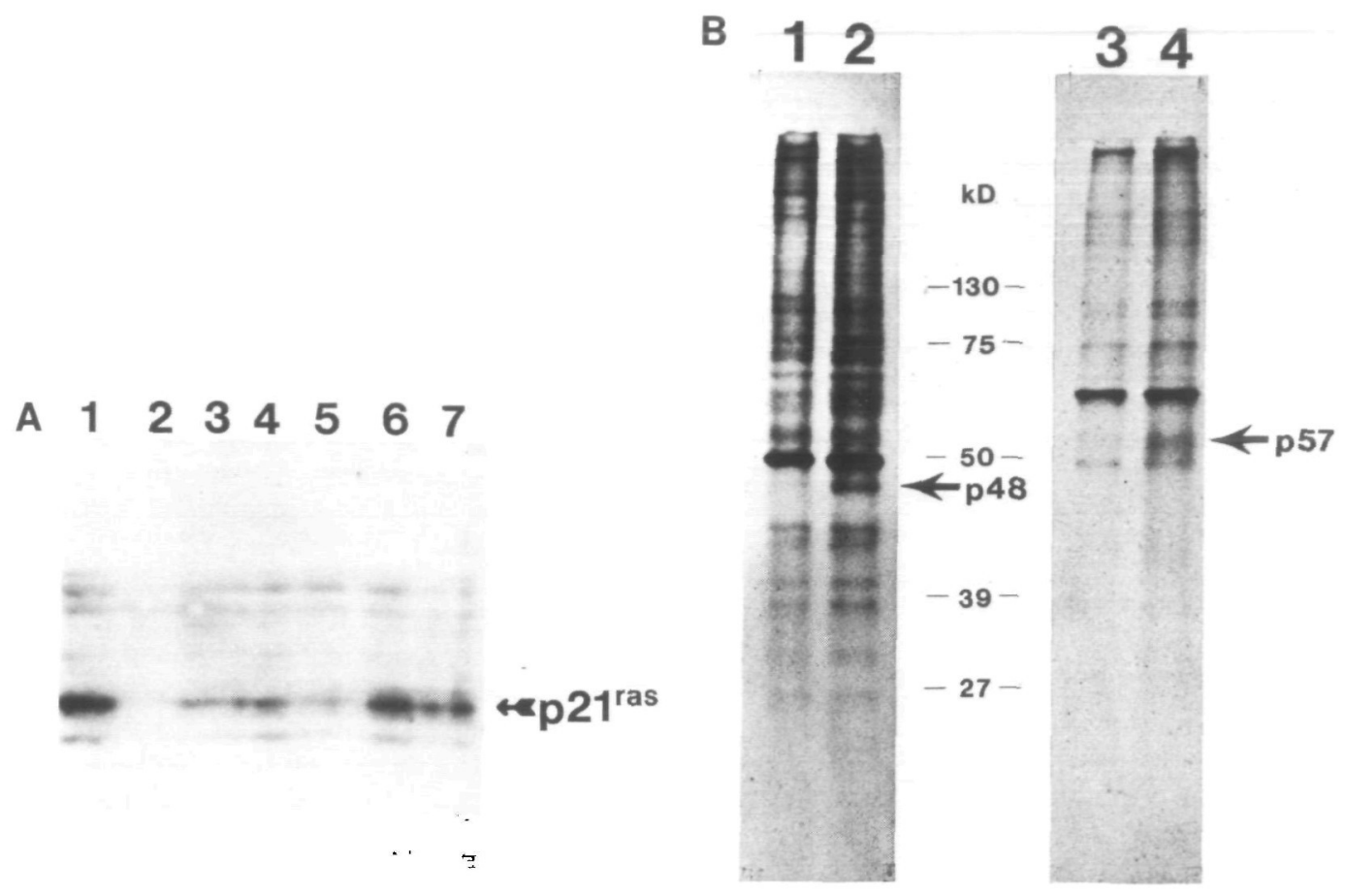

Fig. 2. Expression of the ras, mil and myc oncogene proteins. (A) Membrane proteins from EF43 cells (lane 2), EF43 cells infected with ZIPras virus (lane 1) and five clones of EF43 cells transfected with pSV2neo-EJ, J1 (lane 3); J2 (lane 4); J3 (lane 5); J6 (lane 6); and J7 (bane 7) were separated on a 14\% SDS-polyacrylamide-gel. After transfer to nitrocellulose, ras-specific proteins were visualized by treatment of the filter with anti-p21 ras followed by incubation with iodinated protein A. The p21 ras protein is marked. (B) EF43 cells infected with ZIPneaSV(X) (lanes 1 and 3), ZIP-mil (lane 2) or ZIP-myc (lane 4) virus were cultured in DMEM with $10^{-5} \mathrm{M}$ methionine plus $200 \mu \mathrm{Ci}\left[{ }^{35}\right.$ S]methionine for $3 \mathrm{~h}$. Total cell proteins were extracted and immunoprecipitated with anti-mil (lanes 1 and 2 ) or anti-myc (lanes 3 and 4 ) serum. The anti-mil serum specifically precipitates a protein of $48 \mathrm{kd}$. The anti-myc serum specifically precipitates $p 57^{m y c}$. The positions of reference standard proteins are marked.

Introduction and expression of the oncogenes ras, myc and mil in the EF43 mammary cell line

The plasmid pSV2neo-EJ containing the activated c-Ha-ras gene and the gene for neomycin resistance was transfected into the EF43 cell line. G418-resistant clones were selected and grown into mass culture for Southern blot analysis. Five cell clones (J1, $\mathrm{J} 2, \mathrm{~J} 3, \mathrm{~J} 6$ and $\mathrm{J} 7$ ) contained the transfected plasmid and were chosen for further analysis (data not shown).

Retroviral infection has become an attractive method for the introduction of genes into cells (for review see 36). Among the reasons for this are the relatively high efficiency of gene transfer as well as the stability, integrity and low copy number of the acquired proviral DNA. Infection of EF43 cells with virus produced upon transfection of the $\Psi 2$ MoMLV packaging cell line (29) with pZIPneoSV $(X)$ proceeds with high efficiency (30; N.B. EF43 is referred to as \#43). We therefore sought to use retroviral vectors as an efficient means of introducing oncogenes into the EF43 cell line.

The pZIPneoSV $(X)$, pZIPras, pZIPmil and v-myc-containing pMMCV-neo plasmids (Figure 1) were independently transfected into the $\$ 2$ MoMLV packaging cell line (29) and the virus produced used to infect EF43 cells. G418-resistant populations of EF43 cells independently infected with ras-containing virus (EF43zip-ras-pop), the mil-containing virus (EF43zip-mil-pop), and the empty ZIPneoSV $(X)$ vector (EF43zip-pop) were established. In addition, a clone of EF43 cells infected with myccontaining virus (EF43myc) was obtained. Southern blot analysis of the infected EF43 cell populations showed that each has acquired the appropriate viral DNA (data not shown).

Expression of intraduced oncogenes in EF43 cells Expression of the ras oncogene in the pSV2neo-EJ-transfected

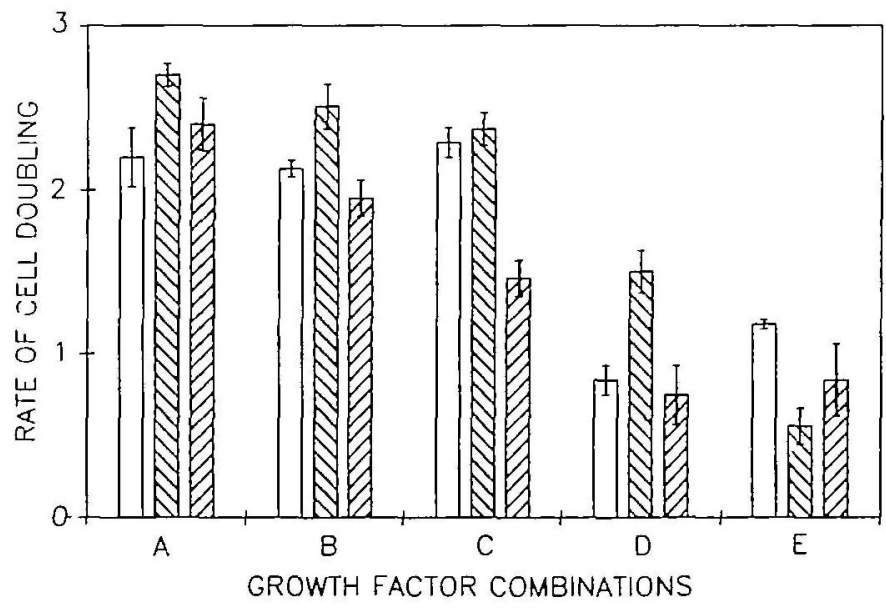

Fig. 3. Graphic representation of growth factor dependence of EF43 cells. The rate of growth from duplicate points of cells grown logarithmically over a period of 6 days was determined in medium containing (A) $0.5 \%$ fetal calf serum, $1 \mu \mathrm{g} / \mathrm{ml}$ insulin and $5 \mathrm{ng} / \mathrm{ml}$ EGF; (B) $0.5 \%$ fetal calf serum and $5 \mathrm{ng} / \mathrm{ml}$ EGF; (C) $0.5 \%$ fetal calf serum and $1 \mu \mathrm{g} / \mathrm{ml}$ insulin; (D) $0.5 \%$ fetal calf serum; (E) $5 \mathrm{ng} / \mathrm{ml}$ EGF and $1 \mu \mathrm{g} / \mathrm{ml}$ insulin. Growth rate of EF43 cells infected with the ZIPneoSV $(X)$ virus is shown by open blocks, of EF43 cells infected with the ZIP-ras virus, EF43zip-ras-pop, by descending shading (left to right) and of EF43 cells infected by the ZIP-mil vinus, EF43zip-mil-pop, by ascending shading (left to right). The error bars indicate the deviation of the actual data from the plotted mean.

EF43 cell lines and the ZIP-ras-infected EF43 cell population was analysed by Western blotting of crude membrane extracts (Figure 2A). Little if any $\mathrm{p} 21^{\text {ras }}$ is detected in the EF43 cell line 
(lane 2). Relatively high levels of $\mathrm{p} 21^{\text {ras }}$ are detectable in both the virus-infected EF43zip-ras-pop (lane 1), and the five pSV2neo-EJ-transfected cell clones J2 (lane 4), J6 (lane 6) and $\mathrm{J} 7$ (lane 7 ) and lower levels in cell clones J1 (lane 3) and J3 (lane 5). The expression of the mil and myc proteins was investigated by immunoprecipitation. A mil-specific protein of $48 \mathrm{kd}$ is detected in the ZIP-mil-infected population of EF43 cells (Figure 2B, lane 2) which is not present in control ZIPneoSV(X) virus-infected cells (Figure 2B, lane 1) or non-infected EF43 cells (data not shown). This protein is smaller than that seen in MH2 virusinfected cells (p100) presumably since it lacks the fused gagspecific sequences (37). A similar raf-related protein of $48 \mathrm{kd}$ has been previously described (38). Expression of the myc gene in the MMCV-neo virus-infected cell line EF43-myc was also investigated. Using anti-myc serum, $\mathrm{p} 57^{m y c}$ is detectable in EF43-myc cells (Figure 2B, lane 4) but not in ZIPneoSV(X) virus-infected EF43 cells (Figure 2B, lane 3 ). The endogenous c-myc protein is expressed at very low levels and is undetectable in this experiment. Expression of p57 $7^{m y c}$ in the EF43-myc cells was also demonstrated by Western blotting (data not shown). Thus, expression of the introduced oncogenes can be detected in each of the ras-, mil- and myc-infected cell lines.

\section{Effect of oncogene expression upon growth of the EF43 cell line}

Oncogenes are known to alleviate dependence upon growth factors (for reviews see 39,40 ). We therefore sought to investigate the effects of expression of oncogenes upon growth factor dependence of the EF43 cell line. To eliminate any effects of clonal variation we compared only the ZIP-ras and ZIP-mil virusinfected populations with the ZIPneo SV(X) virus-infected EF43 cell line. The rate of growth of logarithmically growing control EF43zipSV(X) cells and EF43zip-ras-and EF43zip-mil-infected populations was determined over a 6-day period. EF43 cells grow in the presence of $0.5 \%$ fetal bovine serum supplemented with either EGF or insulin or both (Figure 3). In the absence of both EGF and insulin, the growth rate of the EF43 cells decreases $>50 \%$, indicating a requirement for these factors. Indeed, EF43 cells grow better in medium containing both EGF and insulin but lacking serum than when grown in serum but lacking both growth factors. In the presence of serum, expression of the $\mathrm{Ha}$ ras oncogene increases the growth rate of EF43 cells and reduces their dependency upon EGF and insulin. However, the expression of p21ras appears to have rendered the EF43 cells more dependent on some factor(s) present in serum. This factor(s) seems to co-operate with ras expression to increase the growth rate of the EF43 cells. In contrast, introduction of the v-mil oncogene results in a slight reduction in growth rate in almost all of the growth conditions.

Effect of oncogene expression upon morphology of the EF43 cell line

We investigated the morphology of the EF43 cell line, the populations of virus-infected cells (EF43zip-mil-pop, EF43zipras-pop, EF43zip-pop) and the clones generated either by transfection (pSV2neo-EJ-transfected J series) or virus infection (EF43myc) on plastic. At low cell density, no gross difference in morphology is observed between the EF43 cell line and the EF43 cell line containing ras, mil or myc when cultured on plastic. At confluence, however, EF43 cells expressing the ras oncogene reach a higher cell density and are metabolically more active than the parental EF43 cells or EF43 cells expressing the mil or myc oncogenes (data not shown).

Non-transformed mammary gland cells grown in collagen will form three-dimensional tubular structures reminiscent of mammary gland ducts $(31,41)$. EF43 cells also display this property (R.Ullrich, unpublished observations). Expression of the ras, mil or myc oncogenes does not appreciably affect the morphology of EF43 cells grown in collagen gels (data not shown).

\section{Effect of oncogene expression upon the anchorage- independent growth and tumorigenicity in nude mice of the EF43 cells}

EF43 cells do not grow in an anchorage-independent manner (Table I) and are not tumorigenic in nude mice. Introduction and expression of the ras oncogene either by transfection $(\mathrm{J} 1, \mathrm{~J} 2$, $\mathrm{J} 3$, J6 and $\mathrm{J7}$ ) or by infection with a ras-containing virus (EF43zip-ras-pop) confers upon them the ability to grow in an anchorage-independent manner (Table I). Further, the EF43zipras-pop cells rapidly induce tumors in nude mice and are also tumorigenic in syngeneic animals (Table I). The transfected ras gene is present in DNA extracted from a nude mouse tumor arising from the $\mathrm{J} 3$ cell line (data not shown) indicating the involvement of the ras oncogene in tumorigenesis. Introduction of the v-mil oncogene into EF43 cells also confers upon them the ability to grow in an anchorage-independent manner. However, introduction and expression of $v-m y c$ does not result in anchorage-independent growth of EF43 cells (Table I).

Table I. Effects of oncogenes introduced into EF43 cells upon anchorage-independent growth, in viwo repopulation, and tumorigenicity

\begin{tabular}{|c|c|c|c|c|c|c|}
\hline \multirow[t]{2}{*}{ Cell line } & & \multirow{2}{*}{$\begin{array}{l}\text { Growth in } \\
\text { soft agar" }\end{array}$} & \multirow{2}{*}{$\begin{array}{l}\text { Tumorigenicity in } \\
\text { nude mouse }\end{array}$} & \multicolumn{3}{|c|}{ Repopulation of cleared fat pad } \\
\hline & & & & $\begin{array}{l}\text { No. of mammary } \\
\text { outgrowths }\end{array}$ & $\begin{array}{l}\text { No. of } \\
\text { tumors }\end{array}$ & $\begin{array}{l}\text { Latency } \\
\text { (days) }\end{array}$ \\
\hline $\mathrm{EF} 43$ & Non-transfected & -ve & $0 / 2$ after 7 weeks & & & \\
\hline $\mathrm{J} 1$ & ras transfected & $30 \%$ & $1 / 2$ after 6 weeks & $0 / 16$ & $15 / 16^{e}$ & 40 \\
\hline J2 & ras transfected & $13 \%$ & $2 / 2$ after 2 weeks & $0 / 16$ & $16 / 16^{e}$ & 23 \\
\hline J3 & ras transfected & $40 \%$ & $2 / 2$ after 3 weeks & $0 / 16$ & $16 / 16^{e}$ & 17 \\
\hline J6 & ras transfected & $12 \%$ & $2 / 2$ after 2 woeks & $0 / 16$ & $16 \sqrt{16^{c}}$ & 15 \\
\hline J7 & ras transfected & $25 \%$ & $2 / 2$ after 3 weeks & NT & & \\
\hline EF43zip-pop & Infected & -ve & NT & $7 / 16^{d}$ & $0 / 16^{8}$ & \\
\hline EF43zip-ras-pop & Infected & $22 \%$ & $2 / 2$ after 5 weeks & $0 / 16$ & $16 / 16^{e}$ & 38 \\
\hline EF43zip-mil-pop & Infected & $33 \%$ & NT & $0 / 16$ & $9 / 16^{f}$ & 54 \\
\hline $\mathrm{EF} 43 m y c$ & Infected & -ve & NT & $4 / 16^{d}$ & $0 / 16^{8}$ & \\
\hline
\end{tabular}

$1 \times 10^{5}$ cells plated.

${ }_{1} \times 10^{6}$ cells injected.

$c_{2} \times 10^{5}$ cells injected.

Normal ductal outgrowth.
'Undifferentiated morphology.

'Differentiated morphology.

BAnimals observed for 54 days.

NT, not tested. 
Effect of oncogene expression upon the repopulation of the cleared normal mammary fat pad

Normal ductal outgrowths can be observed when EF43 cells are reimplanted into the cleared mammary fat pad (Figure 4A). Reintroduction of EF43 cells infected with the empty ZIPneaSV(X) virus, EF43zip-pop, also resulted in normal ductal repopulation in 7 out of $16(44 \%)$ mice (Table I). However, introduction and expression of the Ha-ras oncogene both in the $\mathrm{J}$ series and in the EF43zip-ras-pop totally abolishes this repopulation and instead results in the rapid and efficient (100\%) induction of tumors (Table I). These tumors are histologically undifferentiated (Figure $4 \mathrm{~B}, \mathrm{a})$. The introduction of the v-mil oncogene into EF43 cells also leads to rapid tumor formation (Table I). However the tumors derived from expression of the mil gene are histologically highly differentiated (Figure 4B,b). Expression of the v-myc gene does not interfere with the normal repopulation of the mammary gland and these cells are not tumorigenic (Table I). When mice carrying normal ductal outgrowths derived from the EF43 cells, the EF43zip-pop cells or the EF43myc cells received pituitary isografts, the ductal outgrowths became alveolar, indicating a normal differentiation response to pituitary hormones (Figure 4A, inset).

\section{Discussion}

Relatively little is known about the effects of oncogenes on epithelial cells. Among the reasons for this are the difficulties in obtaining and culturing primary epithelial cells, and the difficulties involved in the introduction of oncogenes into these cells which are generally refractile to gene transfer using conventional techniques. The EF43 cell line divides indefinitely in culture, differentiates in vivo and is readily transfectable and infectable (30). Since the EF43 cell line is also non-tumorigenic, it appears to represent the best available cell line for studying the effects of cloned oncogenes upon differentiation parameters of normal mammary epithelium, and the potential involvement of such oncogenes in mammary tumorigenesis. We have introduced the Ha-ras, v-mil and v-myc oncogenes independently into this cell line and measured the effects of expression of these genes upon a range of parameters.

Our results were not affected by the method of introduction of the genes (transfection versus infection) or whether cell clones or populations were analysed. The introduction and expression of either the activated cellular or viral homolog of the Ha-ras oncogene resulted in a tumorigenic conversion grossly characterized by the ability to grow in an anchorage-independent
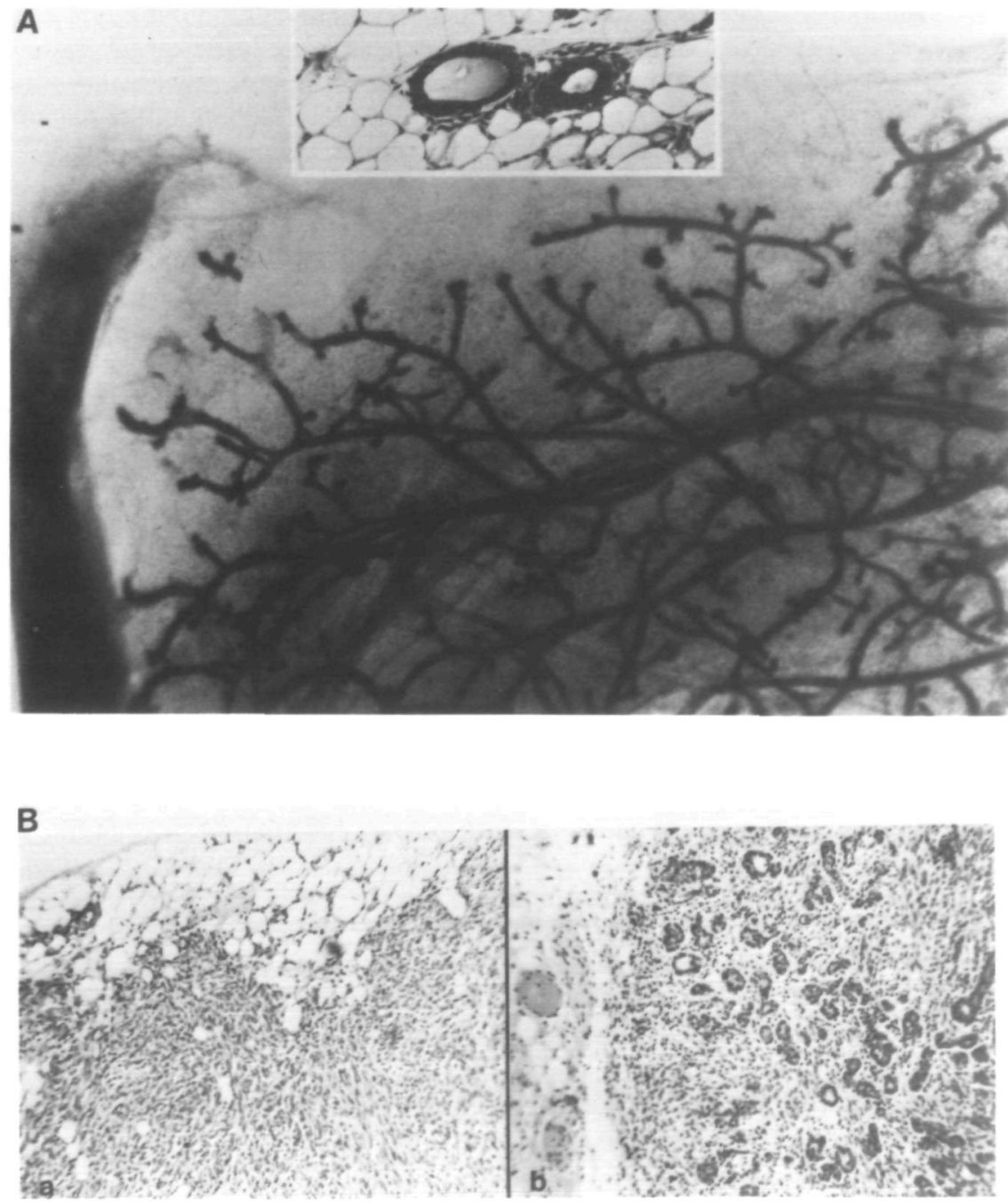

Fig. 4. (A) Mammary gland repopulated with EF43 cells at passage 18. The inset shows the histology of alveolar differentiation after pituitary isograft. (B) Histology of tumors from reimplantation into the cleared mammary fat pads of BALB/c mice. (a) A poorly differentiated anaplastic tumor formed after repopulation with the ras transfected clone $\mathrm{J} 1$. The other ras-transfected cell clones and ras-infected cell population also formed anaplastic tumors of similar histology (data not shown). (b) A well-differentiated adenocarcinoma formed by EF43 cells (EF43zip-mil-population) infected with the v-mil-containing retrovirus. 
manner and the formation of tumors in both nude and syngeneic animals (Table I). Similar results have been obtained after transfection of another mammary cell line, NMuMG, with the Ha-ras oncogene (42). Since our interest is to determine the effects of oncogenes potentially involved in mammary tumorigenesis upon mammary gland cell growth and differentiation, we chose to investigate parameters relevant to the mammary gland.

Although expression of ras does not affect the morphology of the EF43 cells either on plastic or within collagen matrices, the growth rate of the EF43 cells is increased and their requirement for EGF and insulin is reduced (Figure 3), implying that in vivo such transformed cells are no longer responsive to growth factor control of proliferation. However, expression of $\mathrm{p} 21^{\text {ras }}$ does not reduce the requirement for serum, indicating that serum may contain additional factors which co-operate with $\mathrm{p} 21^{\text {ras }}$ to increase the overall growth rate of the EF43 cells. This factor(s) is clearly not EGF or insulin. Recently it has been shown that a factor(s) present in serum may enhance the emergence of tumor cells upon transfection of the Ha-ras oncogene into fibroblasts. This factor does not appear to be a known growth factor (43). Expression of Ha-ras prevents the in vivo parameter of repopulation of the cleared mammary fat pad by the EF43 cells, and instead results in the rapid formation of anaplastic tumors. Anaplastic tumors are indicative of the later stages of mammary tumor progression. The EF43 cells infected with retrovirus lacking an oncogene are still able to participate in normal repopulation of the cleared mammary fat pad, indicating that expression of the Ha-ras oncogene disrupts normal differentiation.

The v-mil gene was originally isolated from the avian carcinoma retrovinus $\mathrm{MH} 2$ which also carries a second oncogene, $v$-myc (23). Deletion mutants of $\mathrm{MH} 2$ suggest that $\mathrm{v}-m y c$ is the primary oncogene of this virus whilst v-mil has auxilliary oncogenic functions (44). In contrast, the murine homolog, v-raf, found in the virus 3611-MSV, efficiently transforms established (20) as well as primary epithelial cells and established fibroblasts (21). In view of the involvement of the mil/raf oncogene family in carcinomas $(20,21)$, we have investigated the effect of introduction and expression of the v-mil oncogene in EF43 cells. A milrelated protein of $48 \mathrm{kd}$ is detected in EF43 cells infected with the v-mil-containing virus. This protein lacks the gag portion of p100gag-mil found in $\mathrm{MH} 2$ virus-infected cells and has the same mobility as a raf-related protein (38). Expression of this protein results in transformation of mammary epithelial cells. The v-mil oncogene, like Ha-ras, induced anchorage-independent growth in the EF43 cells (Table I) without any gross changes in cell morphology. In contrast to ras expressing cells, this is not accompanied by an increase in growth rate or an alleviation of growth factor dependence since EGF and insulin are required for growth (Figure 3). Expression of v-mil abolishes the ability of the EF43 cells to repopulate the cleared mammary fat pad and instead leads to the formation of differentiated adenocarcinomas (Figure 4). Thus this truncated form of the mil gene has a transforming activity in mammary epthelial cells and could play a role in early stages of transformation of the mammary gland.

The myc gene has been implicated in both human $(11,12)$ and mouse (45) mammary carcinogenesis. Introduction and expression of the $v-m y c$ by infection with the MMCV-neo retrovirus (25) did not cause transformation of the EF43 cells, as judged by the parameters we have tested. In accordance with the lack of transformation, the ability of these cells to repopulate the cleared mammary fat pad and respond to pituitary hormones was unaffected (Table I). Recently it has been shown that myc has no apparent effect on established fibroblasts of mammalian $(46,47)$ or avian $(48)$ origin. It is possible that the levels of $v-m y c$ expression may not be sufficient to affect the EF43 cells. However, using a pan-myc-specific antiserum we were only able to detect $\mathrm{v}-m y c$, indicating a much higher expression than of c-myc. Since EF43 cells grow indefinitely in culture, it is probable that some immortalizing event has already occurred. This may have rendered this cell line refractile to the effects of expression of the myc oncogene, which is known to immortalize primary cells (49). The v-mil oncogene has previously been regarded as a potentiating oncogene, having no intrinsic transforming ability. However, EF43 cells expressing v-mil are clearly tumorigenic in vivo. If a myc-like event had already occurred in these cells, $v$-mil may potentiate that effect resulting in neoplastic characteristics.

Taken together, these data suggest that mammary tumorigenesis proceeds by a number of stages, each of which is accompanied by a concomitant loss of differentiation. Since the cell line that we have chosen shows indefinite growth in vitro, it is not 'normal'; however, the EF43 cell line is still responsive to factors that control mammary gland growth and differentiation. Introduction and expression of a myc oncogene does not affect this response. Thus although we cannot be certain whether indefinite growth (immortalization) is a prerequisite for mammary tumorigenesis, it is not sufficient per se to cause the development of mammary neoplasia since it does not appreciably disrupt the differentiative response of the mammary gland. The activation of a cellular oncogene, functionally similar to mil/raf, in cells that have already acquired the ability to proliferate indefinitely, leads to a relatively differentiated tumor, the growth of which is still dependent upon growth factors. Presumably the next stage(s) in the progression towards overt mammary tumorigenesis is the loss of growth control, a stage that can be partially achieved by activating the ras oncogene. This would completely free the mammary cell from growth control and contribute to its invasiveness.

Our description of the molecular events that occur in mammary tumorigenesis would accommodate earlier observations that, at least in some mouse strains, the mammary tumor is reversible-appearing during pregnancy when hormonal growth stimulation is present, then regressing (growth factor responsive tumor) and after three or four pregnancies becoming pregnancy (and growth factor) independent (18). Rapid growth favors the accumulation of mutations required for the progression to the overt mammary tumor. In this light it is interesting that both int-1 and int-2 are putative embryonic growth factors $(50,51)$ that are inappropriately expressed in mammary tumors, and may contribute to, but are probably not the primary cause of mammary tumors.

\section{Acknowledgements}

We would like to thank Heidi Birk, Iqbal Garcha and Rolf Müller for excellent technical assistance. We also gratefully acknowledge the expert animal care rendered by Elga Schloeffli. We would like to acknowledge the help and support of Dr Roland Ball and Dr Bernd Groner (Ludwig Institute, Bern) in whose laboratories this work was initiated. This work was supported in part by NIH grant 7 R01-CA45123-01, in part sponsored by the Office of Health and Environmental Research, United States Department of Energy, under Contract DE-ACO5-840R21400 with Martin Marietta Energy Systems, Inc. and in part by grant CA 43322 from the National Cancer Institute.

\section{References}

1. Fasano,O., Birnbaum,D., Edlund,L., Fogh,J. and Wigler,M. (1984) New human transforming genes detected by a tumorigenicity assay. MoL Cell. Biol. 4. $1695-1705$. 
2. Horan-Hand,P., Thor,A., Wunderlich,D., Muraro,R., Caruso,A. and Schlom,J. (1984) Monoclonal antibodies of predefined specificity detect activated ras gene expression in human mammary and colon carcinomas. Proc. Natl. Acad. Sci. USA, 81, 5227-5231.

3. DeBortoli,M.E., Abou-Issa,H., Haley,B.E. and Cho-Chung,Y.S. (1985) Amplified expression of p21 ras protein in hormone-dependent mammary carcinomas of humans and rodents. Biochem. Biophys. Res. Commun., 127, $699-706$.

4. Ohuchi,N., Thor, A., Page,D.L., Horan-Hand,P., Halter,S.A. and Schlom,J. (1986) Expression of the 21000 molecular weight ras protein in a spectrum of benign and malignant human mammary tissues. Cancer Res., 46, 2511-2519.

5. Kraus,M.H., Yuasa,Y. and Aaronson,S.A. (1984) A position 12-activated $H$-ras oncogene in all HS578T mammary carcinosarcoma cells but not normal mammary cells of the same patient. Proc. Natl. Acad. Sci. USA, 81, $5384-5388$

6. Kraus,M.H., Popescu,N.C., Amsbaugh,S.C. and King,C.R. (1987) Overexpression of the EGF receptor-related proto-oncogene erbB-2 in human mammary tumor cell lines by different molecular mechanisms. EMBO J., 6, 605-610.

7. Filmus,J., Pollak,M.N., Cailleau,R. and Buick,R.N. (1985) MDA-468, a human breast cancer cell line with a high number of epidermal growth factor (EGF) receptors, has an amplified EGF receptor gene and is growth inhibited by EGF. Biochem. Biophys. Res. Commun., 128, 898-905.

8. Filmus,J., Trent,J.M., Pollack,M.N. and Buick,R.N. (1987) Epidermal growth factor receptor gene amplified MDA 468 breast cancer cell line and its nonamplified variants. Mol. Cell. Biol., 7, 251-257.

9. King,C.R., Kraus,M.H. and Aaronson,S.A. (1985) Amplification of a novel verbB-related gene in a human manmary carcinoma. Science, 229, 974-976.

10. Slamon,D.J., Clark,G.M., Wong,S.G., Levin,W.J., Ullrich,A. and McGuire,W.L. (1987) Human breast cancer. correlation of relapse and survival with amplification of the HER-2/neu oncogene. Science, 235, 177-182.

11. Kozbor,D. and Croces,C.M. (1984) Amplification of the c-myc oncogene in one of five human breast carcinoma cell lines. Cancer Res., 44, 438-441.

12. Escot,C., Theillet,C., Lidereau, R., Spyratos,F., Champeme,M.H., Gest,J. and Callahan,R. (1986) Genetic alteration of the c-myc protoonoogene (MYC) in human primary breast carcinomes. Proc. Natl. Acad. Sci. USA, 83, $4834-4838$.

13. Heston, W.E. and Vlahakis, G. (1971) Mammary tumors, plaques, and hyperplastc alveolar nodules in various combinations of mouse inbred strains and the different lines of the mammary tumor virus. Int. J. Cancer, 7, 141-148.

14. Nusse,R., van Ooyen,A., Cox,D., Fung, Y.K. and Varmus,H. (1984) Mode of proviral activation of a putative mammary oncogene (int-1) on mouse chromosome 15. Nature, 307, 13l-136.

15. Dickson,C., Smith,R., Brookes,S. and Peters,G. (1984) Tumorigenesis by mouse mammary tumor virus: proviral activation of a cellular gene in the common integration region int-2. Cell, 37, 529-536.

16. Gallahan,D., Kozak,C. and Callahan, R. (1987) A new common integration region (int-3) for mouse mammary tumor virus on mouse chromosome 17. J. Virol., 61, 218-220.

17. Gray,D.A., McGrath,C.M., Jones,R.F. and Morris,V.L. (1986) A common mouse mammary tumor virus integration site in chemically induced precancerous mammary hyperplasias. Virology, 148, 360-368.

18. Peters, G., Lee,A.E. and Dickson,C. (1984) Activation of cellular gene by mouse mammary tumour virus may occur early in mammary tumour development. Nature, 309, 273-275.

19. Gray,D.A., Jackson,D.P., Percy,D.H. and Morris,V.L. (1986) Activation of int-1 and int-2 loci in GRf mammary tumors. Virology, 154, 271-278.

20. Keski-Oja,J., Rapp,U.R, and Vaheri,A. (1982) Transformation of mouse epithelial cells by acute murine leukaemia virus 3611 : inhibrtion of collagen synthesis and induction of novel polypeptides. J. Cell Biochem, 20, 139-148.

21. Rapp,U.R., Cleveland,J.L., Fredrickson,T.N., Hołmes, K.L., Morse,H.C.,III, Jansen,H.W., Patschinsky,T. and Bister,K. (1985) Rapid induction of hemopoietic neoplasms in newbon mice by a raf $(m i l) / m y c$ recombinant muine retrovinus. J. Virol., 55, 23-33.

22. Hager,G.L., Chang,E.H., Chan,H.W., Garon,C.F., Israel,M.A., Martin, M.A., Scolnuck,E.M. and Lowy,D.R. (1979) Motecular cloning of the Harvey sarcoma virus closed circular DNA intermediates: initial structural and biological characterization. J. Virol., 31, 795-809.

23. Jansen, H.W., Patschinsky,T. and Bister,K. (1983) Avian oncovinus MH2: molecular cloning of proviral DNA and structural analysis of viral RNA and protein. J. Virol., 48, 61-73.

24. Cepko,C.L., Roberts,B.E. and Mulligan,R.C. (1984) Construction and applications of a highly transmissible murine retrovirus shuttle vector. Cell. 37. $1053-1062$

25. Wagner,E.F., Vanek,M. and Vennstrom,B. (1985) Transfer of genes into embryonal carcinoma cells by retrovirus infection: efficient expression from an internal promoter. EMBO J., 4, 663-666.

26. Southern,P.J. and Berg,P. (1982) Transformation of mammalian cells to antibiotic resistance with a bacterial gene under control of the SV40 early region promoter. J. Mol. Appl. Genet., 1, 327-341.

27. Shih,C. and Weinberg,R.A. (1982) Isolation of a transforming sequence from a human bladder carcinoma cell line. Cell, 29, 161-169.

28. Salmons,B., Groner,B., Calberg-Bacq,C.M. and Ponta,H. (1985) Production of mouse mammary tumor virus upon transfection of a recombinant proviral DNA into culnured cells. Virology, 144, 101-114.

29. Mann,R., Mulligan,R.C. and Baltimore,D. (1983) Constnuction of a retrovinus packaging mutant and its use to produce helper-free defective retrovirus. Cell. $33,153-159$.

30. Günzburg,W.H. and Salmons,B. (1986) Mouse mammary tumor vinus mediated transfer and expression of neomycin resistance to infected cultured cells. Virology, 155, 236-248.

31. Jones,W. and Hosick,H.L. (1986) Collagen concentration as a significant variable for growth and morphology of mouse mammary parenchyma in collagen matrix culture. Cell. Biol. Int. Rep., 10, 277-286.

32. DeOme,K.B., Miyamoto,M.J., Osbom,R.C., Guzman,R.C. and Lum,K (1978) Detection of imapparent nodule-transformed cells in the mammary gland tissues of virgin female BALB/cfC3H mice. Cancer Res., 38, 2103-2111.

33. Fry,R.J.M., Garcia,H.E., Allen,K.H., Sallese,A., Staffaldt,E., Tahmisian, T.N., Devine,R.L., Lombard,L.S. and Ainsworth,E.J. (1976) Effect of pituitary isografts on radiation carcinogenesis in mammary and Harderian glands of mice. In Biological and Environmental Effects of Low-Level Radiation. International Atomic Energy Agency, Vuenna, Vol. I, pp. 213-227.

34. Adams,L.M., Ethier,S.P. and Ullrich,R.L. (1987) Enhanced in vitro proliferation and in vivo tumorigenic potential of mammary eptthelium from BALB/c mice exposed in vivo to gamma-radiation and/or 7,12-dimethylbenzla]anthracene. Cancer Res., 47, 4425-4431.

35. Medina,D., Oborn,C.J., Kittrell,F.S. and Ullrich,R.L. (1986) Properties of mouse mammary epithelial cell lines characterized by in viwo transplantation and in viw immunocytochemical methods. J. Natl. Cancer Inst., 76, $1143-1151$

36. Gilboa,E., Eglitis,M.A., Kantoff,P.W. and Anderson,W.F. (1986) Transfer and expression of cloned genes using retroviral vectors. Biotechniques, 4, $504-512$

37. Martin,P., Henry,C., Denhez,F., Amouyel,P., Bechade,C., Calothy,G., Debuire,B., Stehelin,D. and Saule,S. (1986) Characterization of a MH2 mutant lacking the v-myc oncogene. Virology, 153, 272-279.

38. Motders,H., Defesche,J., Muller,D., Bonner,T.I., Rapp,U.R. and Mulker,R. (1985) Integration of transfected LTR sequences into the c-raf proto-oncogene: activation by promoter insertion. EMBO J., 4, 693-698.

39. Denhardt,D.T., Edwards,D.R. and Parfett,C.L.J. (1986) Gene expression during the mammalian cell cycle. Biochim. Biophys. Acta, 865, 83-125.

40. Weinsten, I.B. (1987) Growth factors, oncogenes and multistage carcinogenesis. J. Cell. Biochem., 33, 213-224.

41. Durtan,E.M., Medina,D. and Butel, J.S. (1985) Comparative analysis of casein synthesis during mammary cell differentiation in collagen and mammary gland development in viro. Dev. Biol., 109, 288-298.

42. Hynes, N.E., Jaggi,R., Kozma,S.C., Ball,R., Muellener,D., Wetherall,N.T., Davis,B.W. and Groner,B. (1985) New acceptor cell for transfected genomic DNA: oncogene transfer into a mouse mammary epithelial cell line. Mol. Cell. Biol., 5, 268-272.

43. Hsiao,W-L.W., Lopez,C.A., Wu,T. and Weinstein,I.B. (1987) A factor present in fetal calf serum enhances oncogene-induced transformation of rodent fibroblasts. Mol. Cell. Biol., 7, 3380-3385.

44. Patschinsly, T., Schroeer,B. and Bister,K. (1986) Protein product of protooncogene c-mil. Mol. Cell. Biol., 6, 739-744.

45. Stewart, T.A., Pattengale,P.K. and Leder,P. (1984) Spontaneous mammary adenocarcinomas in transgenic mice that carry and express MTV/myc fusion genes. Cell, 38, 627-637.

46. Zerlin,M., Julius,M.A., Cerni,C. and Marcu,K.B. (1987) Elevated expression of an exogenous c-myc gene is insufficient for transformation and tumorigenic conversion of established fibroblasts. Oncogene, 1, 19-28.

47. Falcone,G., Summerhayes,I.C., Paterson,H., Marshall,C.J. and Hall,A. (1987) Partial transformation of mouse fibroblastic and epithelial cell lines with the v-myc oncogene. Exp. Cell Res., 168, 273-284.

48. Palmieri,S., Kahn,P. and Graf,T. (1983) Quail embryo fibroblasts transformed by four $\mathrm{v}$-myc-containing virus isolates show enhanced proliferation but are non tumorigenic. $E M B O$ J., 2, 2385-2389.

49. Land,H., Parada,L.F. and Weinberg,R.A. (1983) Tumorigenic conversion of primary embryo fibroblasts requires at least two cooperating oncogenes. Nature, 304, 596-602.

S0. Dickson,C. and Peters, G. (1987) Potential oncogene product related to growth 
W.H.Günzburg at al.

factors. Nature, 326, 833-833.

51. Rijsewijk,F., Schuermann,M., Wagenaar,E., Parren,P., Weigel,D. and Nusse,R. (1987) The Drosophila homolog of the mouse mammary oncogene int-1 is identical to the segment polarity gene wingless. Cell, 50, 649-657.

Received on April 11, 1988; revised on June 13, 1988; accepted on June 16, 1988 